\title{
Hvem er syk og hvem er frisk?
}

\author{
Sykdommene behøver oss, uten oss kan de ikke leve. Behøver vi sykdommene for å vise \\ at vi vantrives i kulturen?
}

For en patolog som har utført eller sett på tusenvis av obduksjoner er begrepet «sykdom» håndfast nok. Hos mennesker over 30 år finnes ganske ofte sykelige forandringer i kroppen. Etter hvert som årene går, er det en større og større andel av befolkningen som går med én eller flere kroniske sykdommer. Tar man et gjennomsnitt av befolkningen, er det knapt noen som ikke har eller har hatt en sykdom. Dessuten finner man ikke sjelden alvorlige sykelige forandringer hos dem som tilsynelatende er friske. De alle fleste mennesker går for $\emptyset$ vrig med ett eller flere sykelige symptomer, selv om de konkret sett ikke har noen som helst sykdom. Med andre ord synes det å foreligge et paradoks -de aller fleste mennesker er både syke og friske samtidig og det er ikke nødvendigvis noe samsvar mellom tilstedeværelse av sykdom og forekomst av symptomer. Likevel kommer vi ikke utenom at symptomer på sykdommer kan være håndfaste og plagsomme nok, særlig ved alvorlige tilstander

Med dette bakteppet er det ikke underlig at sosiale faktorer og livsvaner og holdninger knyttet til historiske epoker kan være avgjørende for hvorvidt folk oppfatter seg som syke eller friske. Dessuten har noen sykdommer forekommet og gitt plagsomme symptomer i visse tidsaldre, mens de ikke eksisterer i dag. På slutten av 1800-tallet pleide «finere» damer å dåne, særlig når de var ute blant mange mennesker. Derfor pleide de alltid å ha med seg en flaske fylt med kamferdråper eller liknende sterktluktende væsker når de var ute i forsamlinger. Den var til å snuse på inntil de «våknet». I samme tidsepoke var diagnosen «hysteri» ganske utbredt hos kvinner. Nå er den blitt sjelden, hvis den overhodet forekommer. Før Den annen verdenskrig var «vandrenyre» en plagsom tilstand. Den så man særlig hos folk som hadde magret raskt av, slik at nyren ble løs og skled nedover mot bekkenet. Hvis kirurgen gikk inn i buken, løftet nyren opp igjen og festet den på bakre bukvegg, ble alt bra igjen. Mirakuløst.

I denne artikkelserien har vi tidligere presentert en artikkel av Gisle Espolin Johnson om «snillisme» og alle de problemene som denne tilstanden kan medføre (1). Med snillisme som utgangspunkt skrev de to psykiaterne Berthold Grünfeld (1932-2007) og Per Sundby (f. 1926) i sin tid en kronikk om det klientskapende samfunn (2). Når folk frikobles fra sine ansvarsbetingede valg fordi samfunnet overtar styringen og definerer alle problemer som behandlingstrengende sykelige tilstander, da blir de rett og slett syke. I tillegg kommer medienes massive omtaler av alt som er galt innen verdens miljø- og ressurssituasjon. Ikke uventet har det nå oppstått et nytt alvorlig og behandlingstrengende syndrom: økoangst. Vi kan faktisk lammes av økoangst fordi miljøtruslene går så sterkt inn på oss. Typiske symptomer er panikkanfall, manglende appetitt, irritabilitet, slapphet og søvnløshet. Tilstanden gir en intens følelse av usikkerhet og sviktende kontroll fordi det autonome nervesystemet er i konstant kriseberedskap (3).

For å bøte på den begredelige globale situasjonen prøver folk å leve sunt på individuell basis, og det kan utarte seg til en epidemisk forløpende gruppesunnhet. Det igjen disponerer for en nyoppstått sykdom som går under navnet ortoreksi, med andre ord en sykelig opptatthet av sunnhet (4). Egentlig betyr ordet rett appetitt, og tilstanden ble beskrevet allerede i 1997 av den amerikanske legen Steven Bratman. Karakteristisk for denne nye sykdommen er at man verken er for tynn eller for tykk, bare sunn - med alle de farene og forpliktelsene som det fører med seg (5). Ikke rart at man blir syk av sånt.

Allerede i 1993 kom professor Karin Johannisson ved Uppsala universitet med et viktig innspill. Hun mente at mange mennesker faktisk hadde behov for sykdom. Når bestemte sykdommer florerte i visse historiske epoker, kunne det forekomme at en rekke presumptivt friske mennesker ble med på lasset: «Jeg vil også være syk.» Men så var de egentlig friske. Hun skrev også en bok med mer omfattende analyse av problemfeltet (6). Nå er det på høy tid at vi tar opp igjen dette viktige innspillet. Vi kan også spørre om det å føle behov for sykdom er normalt eller sykt, og om terapisamfunnet nå vil gripe det begjærlig: «Selvsagt er du syk. Du er meget syk.»

Karin Johannisson er professor i idé- og lærdomshistorie ved Uppsala universitet og har spesialisert seg på medisinsk historie. Hun har et rikt forfatterskap bak seg og har gitt ut en rekke bøker. For arbeidet sitt har hun fătt en rekke utmerkelser og er innvalgt medlem av flere vitenskapsakademier. Ved siden av Johannissons kloke ord i artikkelen, som vi her publiserer på nytt, kan vi også legge oss på sinne hva distriktslege Finn Frost (1891-1953) på Voss i sin tid sa. Han var kjent for sin kjappe replikk og uortodokse væremåte. En gang ble han tilkalt til en fjellgård på Evanger til en kvinne som hadde vært syk og ligget til sengs i flere år. Ingen leger klarte å finne ut hva som feilte henne. Frost lyttet nøye til hva hun forklarte. Så undersøkte han henne grundig og begynte han å kle av seg. Først tok han av seg jakken, deretter slipset og vesten, og til slutt begynte han å dra av seg buksene. Den sengeliggende så forskrekket på ham. Da han gjorde tegn til å ville krype opp i sengen til henne, skrek hun opp: «Kva er det du vil?» Frost svarte på sitt lune vis: «Jeg tenkte det kunne være godt å ligge og hvile et par år, jeg også!» Da skvatt kvinnen ut av sengen. Siden var hun oppegående - og i velbefinnende.

\section{Ole Didrik Lærum}

ole.laerum@gades.uib.no

Ole Didrik Lærum (f. 1940) er professor (adj.) ved Københavns Universitet og professor emeritus ved Universitetet I Bergen

\footnotetext{
Litteratur

1. Johnson GE Snillisme. Tidsskr Nor Lægeforen 2012: 133: 206-9.

2. Grünfeld B, Sundby P. Klientskapende samfunn. Aftenposten 5.12.1991.

3. Karlsen PJ. Lammet av økoangst. A-Magasinet 22.6.2012: 35-7.

4. Rössner S. Orthorexia nervosa - en ny sjukdom? Läkartidningen 2004; 101 : 2835.

5. Drangsholt ÅH. Stadig flere sykelig sunne. Aftenposten 2.12.2011

6. Johannison K. Medicinens öga. Stockholm: Nordstedts förlag, 1990.
} 
Artikkel: Johannison, Karin: Vårt behov av sjukdom. Nord Med 1993; 108: 92-3.

\section{Vårt behov av sjukdom}

Sommaren 1987 rapporterade tidningarna om en ny mystisk sjukdom i USA, i brist på värdigare namn kallad yuppiesjukan. Ett år senare hade den fått ett medicinskt namn: chronic fatigue syndrome och tiotusentals fall var registrerade. Sjukdomen ansågs främst drabba yngre framgångsrika personer i karriären (yuppie = Young Urban Professional). Symtomen var diffusa: extrem trötthet, vaga infektionssymtom, huvudvärk och depression. Läkarna stod frågande. Rörde det sig om ett virus? Varför skulle det då drabba en snävt avgränsad samhällsgrupp? Rörde det sig överhuvudtaget om en sjukdom? Eller om en framskapad sjukdomsbild kring symtom utlösta av social stress?

Varje samhälles sjukdomar speglar samhället självt. Det gäller inte bara ekonomiska, sociala och hygieniska förhållanden, inte bara individernas levnadssätt, arbete och miljö, utan också djupare liggande värderingar, normer och kulturella behov.

Sjukdomar föds och dor. Under sin karriär förses de med namn, symtombild, förklaringar och en växlande uppsättning terapeutiska lösningar. För att nå officiell legitimitet som sjukdom måste de integreras $i$ en medicinsk begreppsvärld. Sjukdom finns först när läkarexpertisen förklarar den för sjukdom, identifierar, klassificerar och upptar den i sitt professionella kodsystem. Att drabbas av en sjukdom som inte låter sig inrymmas i den tillgängliga uppsättningen sjukdomar är som att bryta mot överenskomna normer, att ställa sig utanför. Först när sjukdomen främstår som ällmangiltig, generaliserbar och inte som en individuell avvikelse, lyfts den in i den sanktionerade världen av mänskliga plågor. Sjukdomen institutionaliseras.

På samma sätt som sjukdomsbilder uppstår ur många olika källor, låter de sig upplösas på olika sätt. Ibland avslöjas sjukdomen som en katt bland hermelinerna, en charlatan eller imitatör. Ibland urholkas den genom att dess symtom fångas in av nya eller mer etablerade sjukdomsbilder, ibland för att ingen längre betraktar dem som sjuksymtom. Sjukdomens identitet löses upp, den förtvinar och stöts ut ur den institutionaliserade medicinen. Men samtidigt gäller det omvända fenomenet: om en sjukdom är tillräckligt institutionaliserad, blir den en norm som individen kan inordna sina sjuk- symtom under, eller anpassa dem till. Inom sociologin står begreppet institution bl a «för fasta beteenden som bestäms av ett givet normsystem» (1).

Tydligast åskådliggörs institutionaliseringen och dess mekanismer i den typ av sjukdomar som kan kallas kultur- eller kulturrelaterade sjukdomar.

Med begreppet kultursjukdom kan man mena flera saker. För det första sjukdomar som anses framkallade direkt av kulturen ( $\mathrm{t}$ ex vissa epidemier, olika miljö- och arbetsskador). För det andra sjukdomar som uppkommer bara i en bestämd etnisk kultur ( $\mathrm{t}$ ex sjukdomen kuru på Nya Guinea). For det tredje kan begreppet användas i en vidare mening och avser då hur individen kanaliserar en sjukdomskänsla i en kulturspecifik sjukdomsbild. Kultursjukdomar kännetecknas av att de definieras som sjukdom under en viss tid eller i ett bestämt samhällsrum, för att - med ändrade värderingar och normer - antingen uppslukas av andra sjukdomar eller försvinna därfor att de inte längre betraktas som sjukdom.

\section{Varje tid har sina sjukdomar}

Varje epok har sina kultursjukdomar, vars funktion är att fånga upp behov av kontroll, protest, flykt och tröst. De utgör, speglar och formulerar individens svar på social stress. Till sin karaktär tycks de märkligt anpassade till en slags Zeitgeist. Åren kring franska revolutionen blommade de hysteriska och hypokondriska tillstånden som en spontan reaktion på de extrema politiska och klassmässiga spänningarna. Från hypnotisörernas behandlingsrum rapporterades ett vitt spektrum av förlamningssymtom, skak-, darr- och kramptillstånd, plötslig blindhet, dövhet och stumhet. Under 1800talets första halft tycks tvinsoten, tuberkulosen och melankolin ha odlats som intuitiva förkroppsliganden av romantikens idéinnehåll. Det tuberkulösa utseendet med den avmagrade kroppen, genomskinliga hyn och feberbrinnande ögon blev inkarnationen av ett tillstånd av förhojd sensibilitet och kreativitet.

Kring sekelskiftet 1900 - med det moderna samhällets genombrott - upplevde Europa sig som drabbat av en våg av kultursjukdomar. Sjukdomsbilden neurasteni föddes som ett svar på de förandringar som följde med den galopperande industrialiseringen,

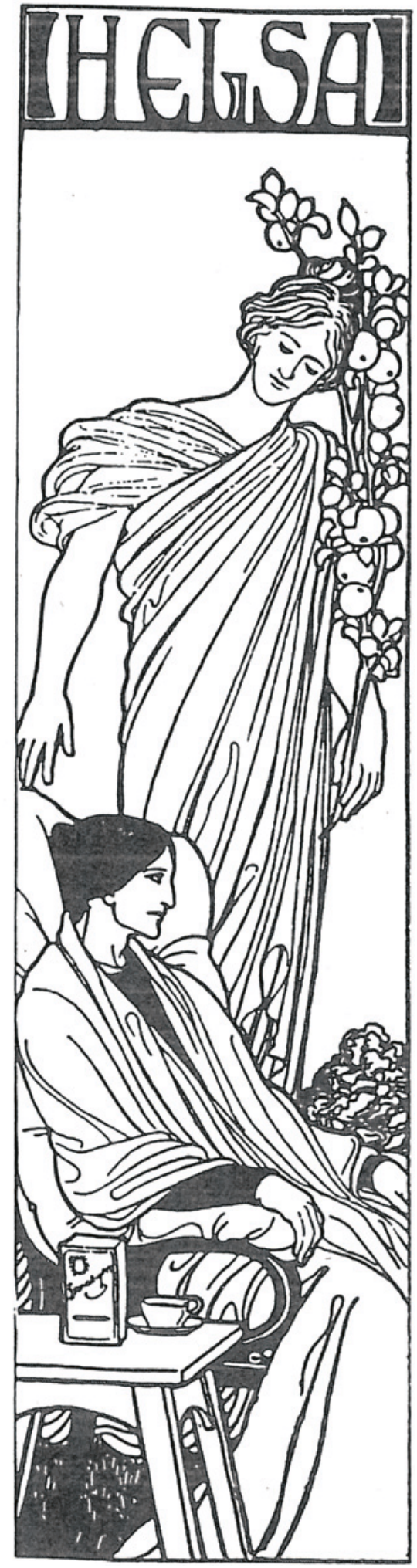

Neurasteni. Illustration ur annons från sekelskiftet för det tyska nervnäringspreparatet Sanatogen. (Uppsala universitetsbibliotek.) 
urbaniseringen och teknifieringen, en tid da värden, normer, sociala roller och mönster ständigt bröt och förvandlades. Med sina symboliska symtom av onaturlig trötthet, kraftlöshet och sårbarhet uppfattades neurastenin redan av samtiden just som ett svar på kulturell stress. Den var en sjukdom för dem som gett sig det moderna samhället $\mathrm{i}$ våld, men som höll på att förlora sin själ. Bleksoten (chloros) var en annan kultursjukdom som med sina karaktäristika av blekhet och trötthet speglade samma föreställning om den moderna tidens press och krav framförallt på unga manniskor.

Ett annat exempel på sjukdomarnas beroende av sin kulturella kontext och individens förmåga att anpassa symtombilden efter tillgängliga mönster, är krigsneuroserna eller vad som idag kallas post-traumatic stress syndrome. Under amerikanska inbördeskriget (1861-1865) dominerade symtom beskrivna som rubbningar i hjärtats verksamhet. Under Första världskriget rapporterades fortfarande hjärtbesvär, men så kallade konversionssymtom, hysteriska och neurasteniska tillstånd (granatchock) hade tagit över den huvudsakliga symtombilden. Under Andra världskriget omvandlades återigen symtomen, nu inom nya diagnostiska kategorier som neuros och depression (2).

\section{Moderna kultursjukdomar}

Idag, just som för hundra år sedan riktas uppmärksamheten mot sjukdom som en metafor för ett samhälle i kris. (Trodde man på en mycket bokstavlig Zeitgeist skulle man kunna kalla fenomenet sekelskiftessjuka; det sena 1700-talet, det sena 1800talet, och nu det sena 1900-talet visar alla en tidsspecifik kultursjuklighet).

Under 1980-talet steg den svenska sjukligheten in i det offentliga samtalet på en rad olika arenor.

Den massmediala arenan blev påtagligt förälskad i sjukdomsbilder och sjukdomsmetaforer. Sjukdom blev en slagkraftig bild för att uttrycka att någonting var fel. De aidssjuka exponerades med sina utmärglade kroppår och sin fläckiga hud som ett slags inkarnationer av dödligt hot. Nya diagnoser, symtom och syndrom föddes i raskt tempo. Inte bara aids. Inte bara kroniskt trötthetssyndrom, utan klamydia och herpes, anorexia och bulimia, oral galvanism och fibromyalgi, el- och bildskärmsallergi, utbrändhet, alexithymi och anomiska syndrom. Man talade om sjuka människor och kroppar, men också om sjuka samhällen och sjuk natur, sjuka marker och vatten, sjuka träd och hus. Var världen sjuk och vi med den?

På den politiska arenan talades det om sjukfrånvaro, sjukskrivningar, arbetsskadeförsäkringar och förtidspensioneringar. Ett nytt ord föddes: «sjukmoral». På vissa arbetsplatser, hävdades det, var en tredjedel av personalen borta varje dag. Det sas att folk var särskilt sjuka inte bara på måndagar utan också på fredagar.

Ekonomerna, politikerna, samhällsingenjörerna var bekymrade. Bara under andra hälften av 1980-talet ökade den genomsnittliga sjukfrånvaron per invånare - och med den kostnaderna for sjukförsäkringen dramatiskt. De mest pessimistiska såg framför sig ett allt bräckligare samhälle, där ett krympande antal arbetsvilliga bar en växande sjukdomsjätte på sina axlar.

I en utmanande artikel i Dagens Nyheter hävdade ekonomiprofessorn och $\mathrm{f} d$ socialdemokratiske riksdagsmannen Bo Södersten att sjukfrånvaron inte gick att forklara med en drastiskt försämrad arbetsmiljö. I stället handlade det om att en av mänsklighetens skönaste drömmar, den om den arbetsfria inkomsten, hade blivit möjlig genom sjukförsäkringssystemet. Människor är inga änglar, hävdade han. Istället är de flesta rationellt kalkylerande varelser som utnyttjar de sociala systemen för att maximera den egna välfärden. Det skulle innebära att sjukfrånvaron inte uttryckte en reell sjuklighet, utan någonting betydligt lättsinnigare (3).

På den medicinska arenan var man också bekymrad. Mätt i läkarbesök, vårdstatistik och läkemedelskonsumtion var det en stor utmaning att relationen mellan den ökade satsningen på sjukvård och ökad hälsa uteblev. Tvärtom - kraven på vården tycktes bara växa.

Vad handlade det om? Blev vi mer och mer sjuka? Varför blev vi i så fall sjuka och i vilka sjukdomar? De gamla vanliga, eller nya? Och om vi inte var sjuka, vad uttryckte sjukligheten då?

Här fanns flera tänkbara förklaringar:

1. Vi blir allt äldre och därmed definitionsmässigt sjukare och mera vårdkrävande.

2. Den medicinska tekniken kan åstadkomma allt mer.

3. Vi tolererar allt mindre av svaghet, handikapp och lidande.

\section{Svar på kulturell stress?}

Men kanske har också vår upplevelse av sjukdom ökat. Med jakten på den optimala livskvaliteten i kombination med stegrade prestationskrav, i en tillvaro där arbete, socialitet, intimitet och sexualitet skall samsas i maximerad symbios, behöver vi kanske sjukdom som en reträtt, en protest och markör.

Sjukdomskanslan skulle alltså kunna beskrivas som ett slags kultursjuklighet, dvs som individens sätt att svara på kulturell stress. Redan vid förra sekelskiftet noterades kroppens förmåga att vid psykisk eller social konflikt utveckla just de symtom som var nödvändiga för att eliminera konflikten. Dessa symtom var anpassade till de sjukdomsbilder som vetenskapen just då tillhandahåll och legitimerade.

Med kulturell förändring har $\mathrm{t}$ ex hysterins uppseendeväckande och neurastenins mondäna symtom försvunnit. De mindre dramatiska och mer diffusa psykosomatiska syndromen, de funktionella störningarna, den kroniska sjukligheten, de obestämda smärt- och värktillstånden har inte bara ersatt äldre tiders symtom som kulturellt konstruerade och legitimerade svar på stress, utan har också kommit att invadera en stor del av den medicinska praktiken.

Den nya sjukligheten - psykosocialt genererade funktionella störningår och kronisk sjuklighet - lanseras som den moderna medicinens främsta utmanare. Man talar om samsjukligheten (sjukdomar relaterade till svårigheter att hantera samhälle, samvaro, samliv). Man talar om olustsjukdomår och frustrationssjukdomar. Gemensamt är att de alla uttrycker någon form av kris.

\section{Att tala om sjukdom}

Är det alltså detta som 1980-talets talande om sjukdom handlar om? Ger vi genom att rikta uppmärksamheten mot sjukdom namn åt en växande vanmaktskänsla, ett slags vantrivsel i kulturen?

Och är det till sist så att all uppmärksamhet på sjukdom som samhällsfenomen i sin tur tillåter oss att bli allt sjukare? När medicinen gett oss nya diagnoser, dvs när sjukdomen finns där som namn och bild, blir den en modell som kan styra ett helt sjukdomsbeteende. Den som behöver det kan välja sjukrollen och också välja vilka symtom han/hon skall använda för att inför omvärlden visa att han/hon vantrivs i kulturen.

Alltså: vi förflyttar vår smärta in i de sjukdomar som vetenskapen namnger och kulturen sanktionerar.

En väsentlig sak skiljer dagens kultursjukdomar från förra sekelskiftets: de har låg status. De låter sig inte styras och behärskas med medicinens ordinarie instrument. De är inte lokaliserade till ett bestämt åtgärdbart organ. Och i första hand tycks denna gäckande diffusa sjuklighet favoriseras av kvinnan. Det är knappast en slump att fibromyalgi ligger i absoluta botten i sjukdomarnas hierarki (4). Neurasteni var ett adelsmärke, en intäkt på (manlig) sensibilitet och förfining. Fibromyalgi associeras till kvinna, lågt socialt värde, tvivelaktighet, problem och oförmåga.

Och ändå förenas de av att uttrycka just en sjukdomsupplevelse. De synliggör känslor 
av olust, ångest, trötthet, främlingskap och meningslöshet. Det betyder att vi behöver sjukdom, om inte annat så som tillflykt eller protest. Sjukdom är en socialt accepterad form av avvikelse. Den tillåter individen att stiga ur de förväntade rollerna och kraven. Man kan inte ringa till jobbet och säga att man inte har mod, ork eller lust. Men man kan ringa och säga att man är sjuk. Sjuk har man alltid rätt att vara.

Att sjukdomarna behöver oss är uppenbart. Utan oss kan de inte leva. Men kanske behöver vi också dem - ibland?

\section{Litteratur}

1. Eisenstadt SN. Social institutions. The international

2. Baker SL. Military psychiatry. I: Comprehensiv textbook of psychiatry, II. Freedman AM, Kaplan HI, Saddock BJ (eds). Baltimore: Williams \& Wilkins 1975: 2355-67.

3. Södersten B. Krispaketet hillier inte. Dagens Nyheter 27.10.1990.

4. Album D. Sykdommers og medisinske spesialiteters prestisje. Nord Med 1991; 106: 232-6.

\section{Författare}

\section{Karin Johannisson}

Docent, ft professor, Institutionen för idéoch lärdomshistoria, Uppsala universitet, Slottet, ing AO, S-752 37 Uppsala. Artikeln ugår från en längre version i Johannisson K. Medicinens öga. Stockholm: Norstedts, 1990. Nord Med 1993; 108: 92-3. 